\title{
Local Ecological Knowledge on the Goliath Grouper Epinephelus itajara (Teleostei: Serranidae) in Southern Brazil
}

\author{
Leopoldo Cavaleri Gerhardinger*, Rosemeri Carvalho Marenzi**, Áthila Andrade \\ Bertoncini*, Rodrigo Pereira Medeiros** and Maurício Hostim-Silva**
}

The goliath grouper Epinephelus itajara is a large sized ( $>400 \mathrm{~kg})$ and critically endangered marine fish, which is protected in many countries, including Brazil. Through the application of semi-structured interviews, we investigated the local ecological knowledge of seven fishermen specialist on catching E. itajara from the Babitonga bay, Santa Catarina, Brazil. Local long-line fisheries for E. itajara seemed to be a disappearing tradition in the studied site, with a detailed inherent local ecological knowledge system, which is also being lost. Our study also showed that fishermen engaged in recent fisheries, such as spear-fishing, can also possess a detailed local ecological knowledge system. Through the analysis of fishermen local ecological knowledge, several aspects of $E$. itajara life history were registered. This species is found in the inner and outer Babitonga bay, from saline waters to areas with a large input of freshwater, and inhabits submerged wooden substrates and artificial reefs such as shipwrecks, mooring pillars and cargo containers. It is known to spawn in December and subsequent summer months in the studied area. Spawning aggregations are usually seen in December (during full moon), being also eventually observed in January and February by our informants. While lobsters, spadefishes and octopuses seem to constitute the most important food items of inner bay E. itajara, outer bay individuals may feed on catfishes, crustaceans and other fish species. The goliath grouper is regarded as pacific and curious fish, but frequently display agonistic behavior in the presence of divers. Based on the perception of well experienced spear fishermen, we hypothesize that E. itajara undertakes seasonal migrations from the inner to the outer bay during summer, and that the studied population is suffering from growth over-fishing. Our data provides a practical evidence of how joining scientific and local ecological knowledge will likely benefit $E$. itajara local conservation and management practices by adding important new biological data into the decision-making process.

O mero Epinephelus itajara é uma espécie de peixe marinho de grandes proporções $(>400 \mathrm{~kg})$ e criticamente ameaçado, protegido em muitos países, incluindo o Brasil. Através da aplicação de entrevistas semi-estruturadas, investigamos o conhecimento ecológico local de pescadores de espinhel e pesca subaquática, especialistas na captura de E. itajara na baía Babitonga, Santa Catarina, Brasil. A pescaria de espinhel direcionada à E. itajara parece ser uma tradição em desaparecimento, com um detalhado sistema de conhecimento ecológico local que está também sendo perdido com o tempo. Nosso estudo mostra que pescadores envolvidos em pescarias recentes, como a pesca subaquática, podem também possuir detalhado sistema de conhecimento ecológico local. Através da análise e integração do conhecimento ecológico local dos informantes, diversos aspectos da história de vida de $E$. itajara foram registrados. Esta espécie é encontrada na porção interna e externa da baía Babitonga, em águas salinas e em água com grande aporte de água doce, habitando resquícios de troncos submersos e recifes artificiais como naufrágios, píers e containeres de carga. Epinephelus itajara é conhecido por reproduzir-se em dezembro e meses subseqüentes de verão na área de estudo. Agregações reprodutivas são usualmente observadas em dezembro (lua cheia), e eventualmente em janeiro e fevereiro. Enquanto lagostas, enxadas e polvos parecem constituir os itens alimentares mais importantes de $E$. itajara habitando o interior da baía, indivíduos de fora da baía Babitonga parecem alimentar-se de bagres, crustáceos e outras espécies de peixe. Os meros são considerados peixes curiosos e pacíficos, mas freqüentemente demonstram comportamento agonístico na presença de mergulhadores. Nós propomos a hipótese de que E. itajara realiza migrações sazonais do interior para o exterior da baía no verão, e que a população estudada está sofrendo de sobrepesca do crescimento. Nossos dados proporcionam evidências práticas de como a integração do conhecimento científico e tradicional pode beneficiar as práticas locais de conservação e manejo de $E$. itajara ao adicionar novas informações biológicas importantes no processo de tomada de decisão.

Key words: Ethnoecology, Marine conservation, Artisanal fisheries, Reef fish, Human ecology.

*Instituto Vidamar, rua São Paulo, 529, 89240-000 Enseada, São Francisco do Sul, Santa Catarina, Brazil. e-mail: leocavaleri@gmail.com **CTTMar, Universidade do Vale do Itajaí, Caixa Postal 360, 88302-202 Itajaí, Santa Catarina, Brazil. www.merosdobrasil.org.br 


\section{Introduction}

The goliath grouper Epinephelus itajara (Lichtenstein, 1822) (Fig. 1) is the largest of the Atlantic Ocean groupers (> $400 \mathrm{~kg}$ ). It is found throughout tropical and subtropical waters of the western Atlantic, from Florida to southern Brazil, including the Gulf of Mexico and the Caribbean and along the western African coast, from Congo to Senegal. It is also reported from the Gulf of California to Peru (Heemstra \& Randall 1993). The species inhabits marine and brackish waters, and it associates with complex and hard substrates such as reef/ rock ledges, rocky bottoms, mangrove shorelines and shipwrecks. Similarly to other species from the genus Mycteroperca and Epinephelus, E. itajara is extremely vulnerable to overfishing, mainly due to critical life history traits such as late sexual maturity (five years), long life ( $>38$ years), strong site fidelity, slow growth and formation of spawning aggregations (Bullock et al., 1992; Huntsman et al., 1999; Sadovy \& Eklund, 1999; Morris et al., 2000; Eklund \& Schull, 2001). Therefore, there is a growing concern on this particular species in the Atlantic Ocean conservation realm (Sadovy \& Eklund, 1999; Hostim-Silva et al., 2005; Ferreira et al., 2006). The World Conservation Union lists E. itajara as a critically endangered species (Chan Tak-Chuen \& Padovani Ferrera, 2006). In Brazil, a five-year fishing moratorium was set as a precautionary management measure in order to allow for a stock evaluation research. However, data on E. itajara landings and even on basic life history traits of this fish are almost inexistent in Brazil. Information, when available, is fragmented and apparently insufficient for a satisfactory evaluation of population status along the Brazilian coast.

In this context, as it has been repeatedly demonstrated, the local ecological knowledge of artisanal fishermen may be unique as a source of information for management and research issues (Johannes, 1998; Seixas \& Begossi, 2001; Sadovy \& Cheung, 2003; Saenz-Arroyo et al., 2005a,b). Local ecological knowledge is defined here as a "body" and a "system" of understandings and know-how that arise through time from a variety of individual and shared experiences and observations, mediated by culture, regarding environmental factors, behavioral attributes, and ecological dynamics (Davis \& Wagner, 2003). Herein we investigate the local ecological knowledge of expert goliath grouper fishermen from southern Brazil, searching to improve the knowledge base on fisheries and biology aspects of what may be the southernmost E. itajara population in the Atlantic Ocean.

\section{Material and Methods}

Study Area. The study was conducted in Babitonga bay, which is one of the largest estuarine systems in southern Brazil (Fig. 2). The bay has approximately $130 \mathrm{~km}^{2}$ of water surface and $6 \mathrm{~m}$ of average depth, with some channels reaching $30 \mathrm{~m}$ deep (IBAMA, 1998). Rocky and fluvial islands are found within the bay, and the bottom is dominated by rock and mud. The area was colonized by Europeans in mid-eigh-

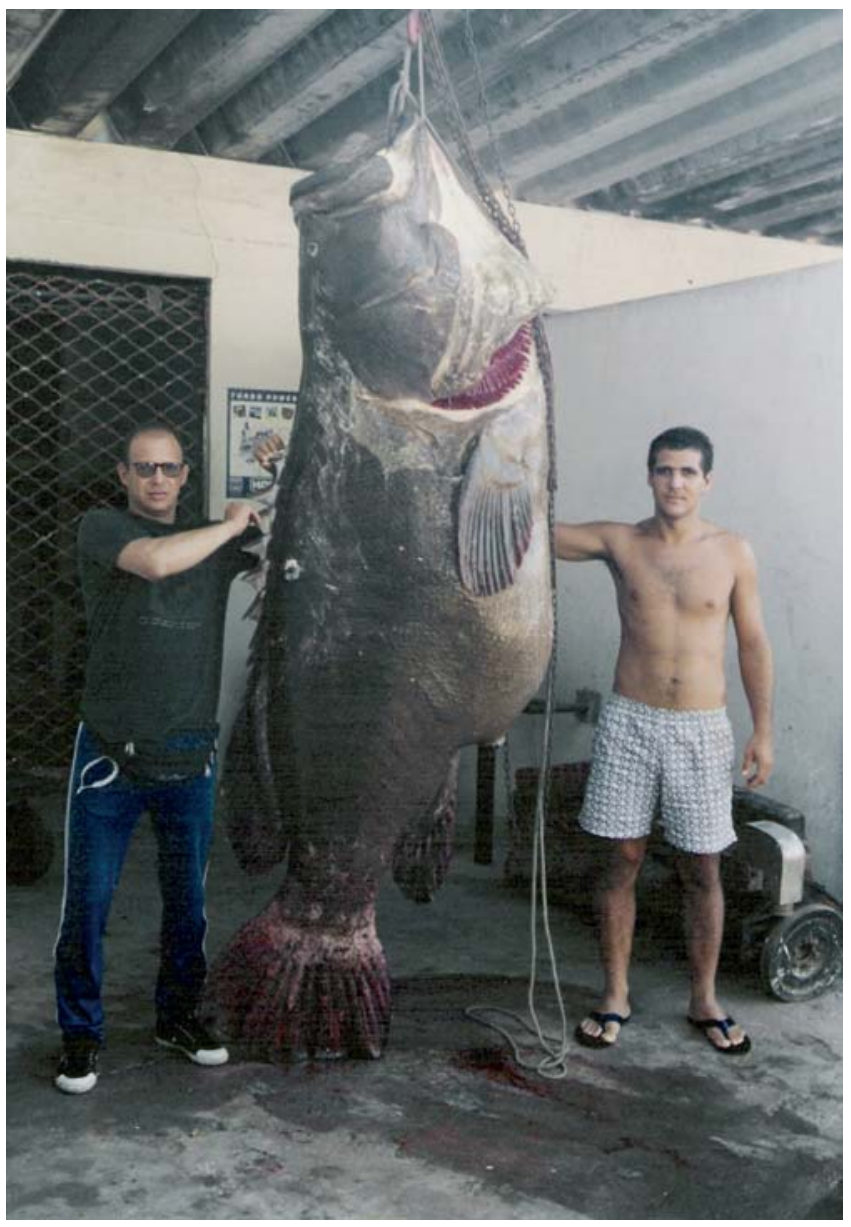

Fig. 1. Epinephelus itajara, $328 \mathrm{~kg}$, caught in Rio de Janeiro $(06 / 12 / 1997)$ by Gilberto Bombieri (Brazilian record of spearfishing). Image gently provided by the CBCS (Confederação Brasileira de Caça Submarina).

teenth century, and holds today approximately 33 communities, 1089 fishermen and 493 small boats, from which only $67 \%$ are motorized (IBAMA, 1998). Among the most used fishing gears are gillnets, bottom trawling, long-line, castnet and "gerival" (tide/motor-driven net which targets shrimps) (Pinheiro \& Cremer, 2004). The main fishing resources are finfishes (mainly Ariidae, Carangidae, Mugilidae, Paralichthyidae, Pomatomidae, Sciaenidae and Serranidae), shrimps, oysters, clams and crabs (IBAMA, 1998; Pinheiro \& Cremer, 2004).

Informant selection. In order to identify those fishermen most knowledgeable about Epinephelus itajara, visits were done to each of the main five local fishermen communities (spending at least 6 hours on each community), from December 2002 to July 2004. On every visit, we approached fishermen, fish markets and fishermen association staff and asked them for references of those who would most likely provide us with the best information on E. itajara. A small number of fishers were recognized as "goliath grouper experts" at each community, so expert references rapidly converged to a few names (2 


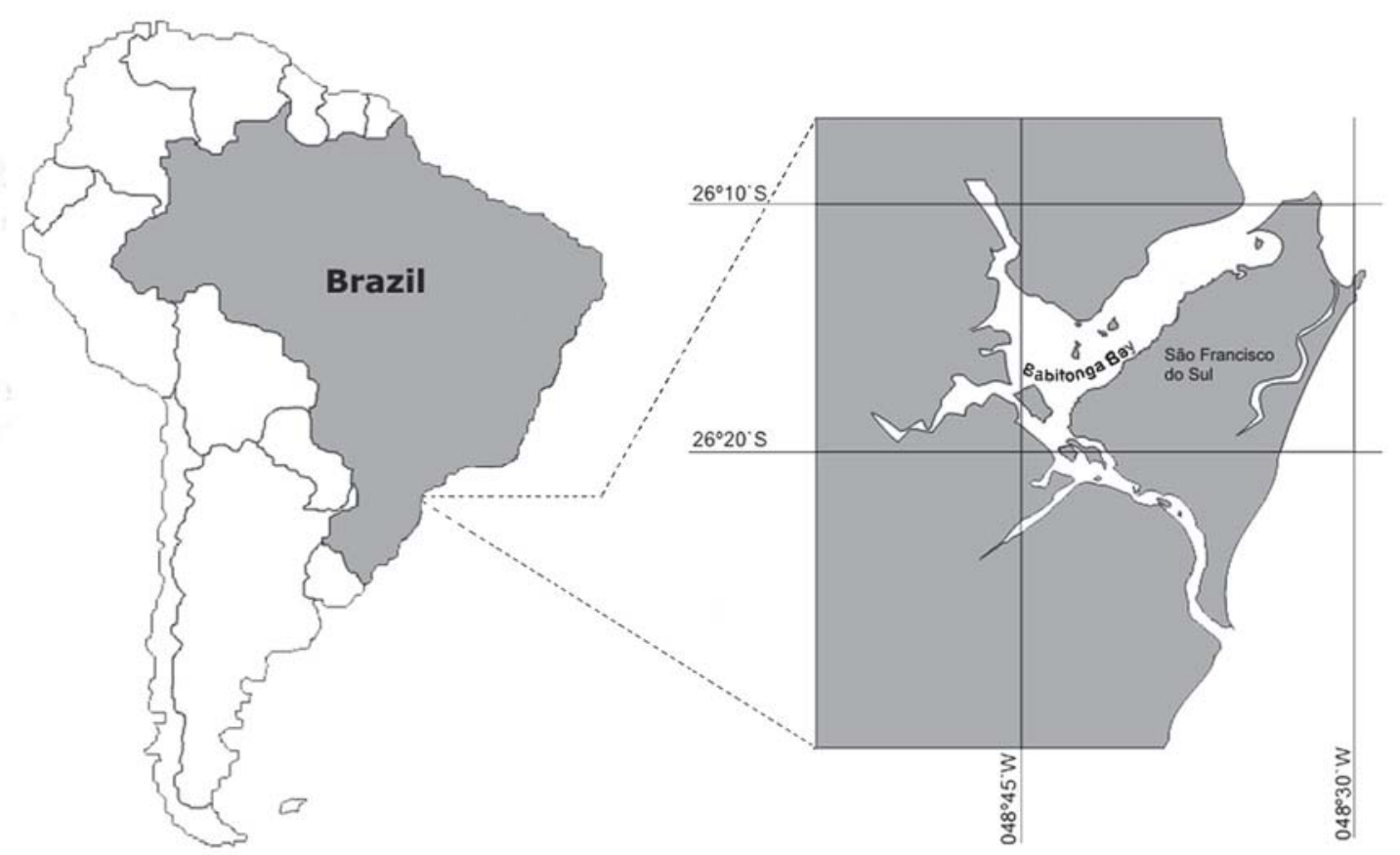

Fig. 2. Babitonga bay and São Francisco do Sul Island, Southern Brazil (Santa Catarina state).

to 3) on each locality. A final selection was done by the corresponding author (LCG) in possession of a final list of fifteen E. itajara specialists indicated by the community. Seven project "informants" were selected, given preference to those fishermen showing an in-depth knowledge content on goliath grouper life traits, practical experience, ability to communicate with the research team, community recognition and most importantly, willingness to participate in the project. Among the seven informants, three are long-line fishermen in the inner Babitonga bay (estuarine dominated environment) and four are spear fishermen in the outer bay (marine dominated and reef environment).

Each informant was interviewed individually (see below) with previous consent. In every occasion, the objectives of the present project were presented and discussed before the data collection.

Data collection and analysis. Each informant was interviewed following a semi-structured conversation in order to record the Local Ecological Knowledge (LEK) on E. itajara. Although the conversation was freely conducted, giving opportunity to the exploration of the informant's knowledge content, some specific topics were pre-determined (Table 1). All encounters were audio recorded under previous consent from informants. To each conversation topic, a comparative table was created to facilitate data analysis. These tables divided knowledge content from informants either as "collective perceptions" (when at least two informants provided similar conclusions on a given topic) or as "individual perceptions" (when conclusions and points of views on any given topic were unique among informants) (e.g. Table 2).

The balance between an open interview and the use of a pre-determined set of conversation topics gave flexibility to our conversations. While this methodology allowed us to investigate specific topics of interest, it also gave us the possibility to explore unexpected and interesting aspects of our informants' LEK (see Huntington, 2000). Structured and standardized questionnaires would be inappropriate to our species-specific approach and research goals, as they could limit the scope of our research to a set of pre-determined questions (see Johannes et al., 2000).

\section{Results}

Epinephelus itajara fisheries. According to our informants and recent regional statistics bulletin on fisheries landings data (UNIVALI, 2002), E. itajara is caught by the following gears: long line set near reef formations in the inner and outer Babitonga bay; industrial bottom trawling fleet (bull and double trawling); artisanal bottom trawling fleet (shrimps); gillnets within Babitonga bay; amateur fishing with rods in the inner bay and; spearfishing in the outer bay.

Fishery data available for E. itajara in the State of Santa Catarina is not representative of the real total landing volume expected (e.g only $513 \mathrm{~kg}$ registered in 2002) given the intensity to which the industrial fleet operates in Santa Catarina. The fishing moratorium is probably reflecting E. itajara underreporting in fisheries bulletins.

Small individuals of up to $15 \mathrm{~kg}$ are occasionally caught by gillnets in the inner Babitonga bay. Young E. itajara $(<1$ $\mathrm{kg}$ ) are caught by small bottom trawling boats in the inner bay and adjacencies. According to our observations, only the long-line fisheries and spear-fishing specifically target $E$. itajara. 
Table 1. Semi-structured interview topics used for local ecological knowledge investigation on the goliath grouper Epinephelus itajara in Southern Brazil.

\begin{tabular}{|c|c|}
\hline General topic features & Specific conversation topics \\
\hline \multirow[t]{4}{*}{ Fisherman profile } & Years of fishing experience. \\
\hline & How the informant started fishing? \\
\hline & How the informant learned to fish (with parents / by himself)? \\
\hline & Activities other than fishing. \\
\hline \multirow[t]{5}{*}{ Activity profile } & Number and type of fishing boats possessed. \\
\hline & Fishing practices developed during the year. \\
\hline & Equipment used on each fishing practice. \\
\hline & Targeted fish (winter/summer). \\
\hline & What environmental conditions take the informant out to fish goliath groupers? \\
\hline \multirow[t]{2}{*}{ Economical aspects } & Is there any economical dependence on goliath grouper fishing? \\
\hline & Goliath grouper chain of commerce, from fishermen to final consumers. \\
\hline \multirow[t]{2}{*}{ Reproduction } & Is the goliath grouper vulnerable? If so, to which fishing artifacts? \\
\hline & $\begin{array}{l}\text { Was mature goliath groupers observed by informants? In which period of the year? From what size up they are seen mature? } \\
\text { How to differentiate sexes? }\end{array}$ \\
\hline Feeding & What does goliath groupers eat? The larger individuals eat the same as the smaller individuals? \\
\hline \multirow[t]{3}{*}{ Behavior } & Goliath groupers produce any sound? In what instances? \\
\hline & Do goliath groupers suffer from any diseases? What are the causes? \\
\hline & Are Goliath groupers aggressive fishes? In what instances? \\
\hline \multirow[t]{3}{*}{ Conservation } & Are there more goliath groupers today or in the past? How is it compared with when you started fishing? \\
\hline & What are the major conservation problems suffered by this species? \\
\hline & What is the opinion of the informant regarding the impact of his fisheries on goliath groupers? \\
\hline \multirow[t]{2}{*}{ Habitat } & What size had the largest goliath grouper observed and when/where it was seen? \\
\hline & How is the environment inhabited by the goliath groupers? Where can the smaller individuals be found? And the large ones? \\
\hline Seasonality & When is the peak goliath grouper fishing season? Are goliath groupers caught in other times of the year? \\
\hline \multirow[t]{2}{*}{ Aggregations } & Where are goliath groupers in winter/summer? \\
\hline & $\begin{array}{l}\text { Have you ever seen or caught many goliath groupers at the same place? Were they mature? How do they behave at such } \\
\text { occasions? When was it seen? }\end{array}$ \\
\hline
\end{tabular}

Spear-fishing. Among our four spear fishermen informants (30, 40, 48 and 83 years old), only one fished solely for recreational purposes (senior informant - one of the first spear fishermen in the region). Spear fishing is a relatively recent practice in Santa Catarina, and according to our senior informant, was introduced in Babitonga bay around 50 years ago. Initially introduced by amateurs (tourists from distant urban centers), spear fishing is today a common practice among local professional fishermen. In the 50's, all equipment was imported from other countries, and the fishing was done only during the warmer months of the years in shallow reefs and nearby fishing spots. As modern and low cost equipments were made available (special suits, fins and spear-guns), spearfishing was gradually being practiced at deeper sites $(>20 \mathrm{~m})$ and under adverse oceanographic conditions (waves, currents and low temperatures). Today, illegal spear-fishing is practiced by some professional fishermen, which use a diverse set of underwater breathing apparatus (e.g. SCUBA).
Thus, fishing power has been progressively increasing due to technological advancements.

Spear fishermen take into account several factors when choosing the most favorable fishing spots, such as the abundance of targeted species and number of fishermen in the water at a given place, tide and current conditions. The fishing success is also closely related to each individual's knowledge of fish behavior and habitat. Thus, a large LEK content is needed to make this fishing activity economically viable.

Apparently, a large part of these fishermen's LEK is acquired during the individuals' life cycle, as most of their families have no tradition on spear fishing. The transmission of LEK through social relations among fishermen of the same generation seems to be also high, as the exercise of sharing experiences with each other is common among both amateur and professional spear fishermen. However, we noticed that sometimes the main and newly discovered fishing spots are kept in secret (LCG, pers. observ.).

Table 2. Example of a comparative table used in the analysis of conversation topics of informants from Babitonga bay (southern Brazil), showing comments on mature goliath grouper Epinephelus itajara.

\begin{tabular}{ll}
\hline & \multicolumn{1}{c}{ Observations on mature E. itajara (Number of citations) } \\
\hline $\begin{array}{l}\text { Collective } \\
\text { Perceptions }\end{array}$ & $\begin{array}{l}\text { Plenty mature goliath groupers are seen, mainly in December (3) } \\
\text { Has not observed because fish is sold gutted (3) }\end{array}$ \\
\hline \multirow{3}{*}{$\begin{array}{l}\text { Individual } \\
\text { Perceptions }\end{array}$} & Almost all that he has ever caught were mature \\
& Maturation happens from November to March (because during this period of time goliath grouper migrates in and off the bay). \\
& Has observed a 22 kg mature female gonad \\
\hline
\end{tabular}


Long-line fishing. Among our three long-line informants (36, 56 and 76 years old), the younger and senior fishermen (son and father) are fully economically dependent on fishing, while the third informant has complementary sources of subsistence. In spite of being a part-time fisherman, the third informant is highly experienced. Obtaining economic subsistence from multiple sources (e.g., small-scale agriculture) is a common practice among fishermen families in Brazil.

Epinephelus itajara has been caught in the inner Babitonga bay for at least 60 years (Tiago, 1941). However, we suspect that the long-line fishing for E. itajara is a much older local tradition, as our senior long-line informant represented at least the third generation of his family practicing it.

The E. itajara long-line fishing gear consists of a main cable with several secondary cables with large hooks (approximately 20 secondary cables and hooks). The long-line is set by the afternoon and is periodically checked in the subsequent mornings and afternoons. As the baits lose attractiveness, they are replaced and the long-line remains fishing for a couple of days. Sometimes fishermen use live baits in order to extend the period of bait duration (long-lines stays longer in the water without bait exchange) and effectiveness (live baits have a higher fishing performance). Long-line fishing with live bait is even more complex and time consuming, as it depends on the operation and possession of LEK on other fishing gears and resources (e.g. long-line with small hooks targeting ariid catfishes).

Socioeconomic aspects. Large individuals of E. itajara are not easily commercialized, because its meat is not highly appreciated and presents a large volume not easyly sold. Long-line informants say that sometimes a large E. itajara would be moored alive to artificial structures near the beach, waiting to be sold in the local market or eventually to neighboring cities.

According to all informants, fishermen are not solely or highly dependent on E. itajara for subsistence or commercialization. It was apparent in the speech of all long-line informants that the E. itajara long-line fishery has not been part of young fishermen's routine. The complexity of this fishing activity, its apparent low capture rate, the popularity of "modern" fishing gears (e.g. gillnets and "gerival") and the fishing moratorium seem to discourage long line practice nowadays.

It is interesting to note the social distance between spearfishing and long-line informants, reflected in the unfamiliarity with each others fishing practices. Although they all live in the same city and explore similar resources (including $E$. itajara), no spear-fishing knew that long-line fishermen actually catch E. itajara in the inner bay during winter. Similarly, no long-line informant knew at that point about the existence of spawning aggregation events. Furthermore, long-line and spear-fishing uses different popular names to designate $E$. itajara (Gerhardinger et al., in press).

\section{Fishermen ecological knowledge}

Reproductive aspects. Long-line informants were not always self-confident when answering questions regarding repro- ductive aspects because they usually do not see fish viscera (fish is sold ungutted to local fish markets).

Three out of four spear-fishing informants were categorical when stating that mature female gonads (Table 2) are usually found in December. Two spear-fishing informants said that reproduction extends to January. Four informants pointed out the high fecundity attained by E. itajara females. Two long-line informants observed the smallest mature individuals with weights ranging from $40-60 \mathrm{~kg}$ in the study area. One of our spear-fishing informants reported a weighed $22 \mathrm{~kg}$ female gonad.

Although two informants recognized that females usually had larger "bellies", on a clear reference to well developed gonads, the perception of sexual dimorphism is not common among informants. However, our senior spear-fishing informant provided us a very detailed report on the differences between male and female behavior in spawning aggregations (Gerhardinger et al., 2006). According to him, the male "takes care" of the female, swimming towards the diver and showing agonistic behavior (territorial defense through the emission of loud, low frequency sounds). Females stay almost motionless above the bottom and thus are easier to catch. With the intention of conserving females (which were always caught with well-developed gonads), he usually decided to catch male individuals (which were thinner and with no oocytes), even if this decision would demand an increased fishing effort.

The spawning aggregations of E. itajara were only seen by our spear-fishing informants. All of them considered that E. itajara aggregates for spawning purposes because fish caught in these occasions had well developed gonads (in advanced maturity phases).

Spawning aggregations are seen in the outer Babitonga bay, usually in December, although one of our informants has observed this event in January and February. On a consensual speech, all spear-fishing informants associated E. itajara aggregations to full moon phases. The exact moment of spawning was not observed by our informants.

Feeding. Long-line informants associated the feeding preferences of E. itajara to the fish's preferred baits and occasional observation of stomach contents. On the other hand, spear-fishing informants were able to visualize natural feeding strategies of E. itajara, besides also observing its stomach contents.

According to spear-fishing informants, the food items preferred by E. itajara are lobsters, the Atlantic spadefish Chaetodipterus faber and octopuses. Long-line informants referred to catfishes (Ariidae) as the preferred E. itajara food item. Other prey items were also mentioned by individual informants (Table 3 ).

Ambush predation was observed by three spear fishermen informants, and E. itajara was also observed predating on the water column, attacking fish schools and even robbing fish caught by fishing gears (e.g. hook and line). 
Table 3. Goliath grouper Epinephelus itajara prey items in Babitonga bay, Santa Catarina, Brazil (data based on local ecological knowledge of fishermen) and in the Northern Hemisphere (following Sadovy \& Eklund, 1999 and references therein). Number of informant citations and scientific names are given in parenthesis.

\begin{tabular}{|c|c|}
\hline \multicolumn{2}{|r|}{ Prey items } \\
\hline Babitonga bay & Northern Hemisphere \\
\hline Lobsters (3) & Lobsters (Palinurus argus, Scyllarides aequinoctialis) \\
\hline Octopuses (Octopus sp.) (2) & Octopuses \\
\hline & Gastropods (Fasciolaria tulipa) \\
\hline Crabs (Menippe sp. and & Crabs (Calappa flammea, Menippe mercenaria, Ovalipes floridanus, Callinectes sp., \\
\hline Callinectes sp.)(2) & Hepatus sp., Rhithropanopeus harrisii, Carpilius carallinus) \\
\hline Catfishes (Genidens genidens / Genidens barbus) (3) & Catfish (Arius felis) \\
\hline Atlantic Spadefish (Chaetodipterus faber) (3) & Atlantic Spadefish (Chaetodipterus faber) \\
\hline Filefish (Monacanthidae) (1) & Scrawled cowfish (Lactophrys quadricornis) \\
\hline Puffers (Sphoeroides sp.) (1) & Puffers (Diodon sp., Chilomycterus schoepfi) \\
\hline Leatherjack (Oligoplites sp.) (1) & Sardine (Etrumeus teres) \\
\hline Blue runner (Carangidae) (1) & Ray (Dasyatis americana) \\
\hline Snook (Centropomus sp.) (1) & \\
\hline Dusky groupers (E. marginatus) (1) & \\
\hline Mullets (Mugil sp.) (1) & \\
\hline Sardines (Clupeidae) (1) & \\
\hline Gobiidae (1) & \\
\hline Shrimps (preyed by juvenile $E$. itajara) (1) & Shrimps (Penaeus duorarum) \\
\hline & Turtles \\
\hline
\end{tabular}

Behavioral aspects. The emission of loud, low-frequency sounds by E. itajara was noted by all spear-fishing informants. The sound is usually heard even before the diver can actually locate the E. itajara underwater, and is sometimes regarded as a strong indicator of its presence at fishing sites. Young E. itajara $(<40 \mathrm{~cm})$ already show this sound producing behavior in aquariums (LCG, pers. observ.).

Physical trauma was regarded by all spear-fishermen as a potential risk of diving closely to large individuals. Such incidents happen when a large fish swims in the diver's direction. One spear-fishing informant also remembered that E. itajara can sometimes suck the divers' arms, releasing it after a few seconds.

According to two long-line informants, dying E. itajara are frequently found floating within the bay. Among the causes cited by these informants, two perceptions were convergent: 1) large amount of fat tissue in the viscera; 2) sudden decrease in water temperature within the bay.

Habitat use. Epinephelus itajara is found in the inner and outer bay, from offshore/marine to low salinity estuarine waters (nearby rivers discharging into the bay). All informants (spear and longline fishermen) agreed that $E$. itajara inhabits rocky reef formations (rocky continental and island shores and outcrops in and outside the bay). In the most internal portions of the Babitonga bay, the species can be found inhabiting submerged remaining portions of trees, which are carried to the estuary during periods of intense raining. According to our informants, E. itajara is also found nearby submerged artificial reefs such as shipwrecks, mooring pillars and cargo containers in the inner and outer bay. Spear-fishing informants referred to the presence of the largest individuals in wide/large rocky caves.

In areas where spear-fishing is commonly practiced (outer bay reefs), fishes from 20 to more than $300 \mathrm{~kg}$ can be observed. Meanwhile, the long-line fishermen (inner bay) catch individuals from 15 to $150 \mathrm{~kg}$ approximately. Our long-line and spear-fishermen informants do not know about the habitat use by E. itajara smaller than $15 \mathrm{~kg}$. These smaller fishes are apparently not vulnerable to fishing gears commonly used by the interviewed fishermen.

Seasonality. Long-line informants agreed that E. itajara is caught year round in the inner Babitonga bay. These informants also pointed out that the capture rate increases in the warmer months. It was suggested by two long-line informants that this fish species might be at deeper areas within the bay during winter.

Spear-fishing informants recognized a much shorter period of time during which E. itajara is available along their fishing sites (outer bay). Although they agree that it is possible to find E. itajara during all the warmer months, during December this fish apparently peaks in abundance. All spearfishing informants also associate the period of increased abundance of this fish with the full moon phase. The observation of E. itajara during winter is said to be rare, but not impossible. Although none of our spear-fishing informants were sure about their knowledge on the species seasonality patterns, they all hypothesized that E. itajara may migrate to other areas during colder months.

Local Conservation Status. Three out of four spear-fishing informants believe that E. itajara are in bad conservation status in the studied region. They justify arguing that throughout their life as fishermen, they have noticed a decrease on the number of individuals sighted in places where they were once abundant. The main causes of such population decline are attributed to anthropogenic impacts (e.g. ilegal fishing with underwater breathing apparatus and pollution) and decreased availability of feeding resources, such as lobsters. Interestingly, all of our long-line informants are optimistic regarding $E$. itajara conservation status within the bay. The abundance is regarded as unchanged or even higher than before. The argu- 
ment sustaining such oppinion is the small number of local fishermen targeting E. itajara. Furthermore, long-line informants argues that there has been a gradual decrease on E. itajara landings, since long-line fishing tradition is being lost.

\section{Discussion}

Epinephelus itajara is the first marine fish subjected to a strict fishing restriction level in Brazil. Although the loss of the E. itajara long-line fishing culture seems to minimize the socioeconomic conflicts that may arise due to the fishing moratorium imposed by the Brazilian government, the socioeconomic impacts of such management measure should be further investigated.

The spawning period of E. itajara peaks in December and extends for an undetermined period of the summer season in our studied area, according to fishermen. In the Gulf of Mexico and Florida, the reproductive period of this fish occurs between June and October, corresponding to the summer months (or wet season) in the Northern Hemisphere (Sadovy \& Eklund, 1999).

Some of our informants have the idea that fish producing a large amount of eggs do not suffer recruitment shortages, opinion shared by many other people in the community (LCG, pers. observ.). However, highly fecund fishes may also suffer biological extinction (Roberts \& Hawkins, 2000; Sadovy \& Cheung, 2003). Despite its high fecundity levels (Sadovy \& Eklund, 1999), E. itajara has a set of life history traits that makes it especially vulnerable to over-fishing (e.g. long living, slow growing, late sexual maturity, strong site fidelity, aggregates to spawn) (Sadovy \& Eklund, 1999), and therefore is a species of conservation concern.

In the Gulf of Mexico, E. itajara individuals enter the adult population when they reach 100-135 cm of total length (Bullock et al., 1992), which corresponds approximately to 40-60 $\mathrm{kg}$, a value similar to that pointed by two of our long-line informants. Although our data from fishermen are fragmented and incomplete regarding maturation size of this fish, precise estimates reached through conventional reproductive biology surveys are far from being viable in Brazil, especially after the fishing moratorium. For instance, the most complete study on E. itajara reproductive biology was done by Bullock et al. (1992), gathering ten years of sparsely and eventually collected samples of fish caught by the artisanal fishing fleet in the Gulf of Mexico.

One of our spear fishing informants reported a female gonad of $22 \mathrm{~kg}$, while the highest value registered so long was $16.36 \mathrm{~kg}$ (Bullock, unpublished data apud Eklund \& Sadovy, 1999).

Colin (1994) indicates that spawning E. itajara assumes a darker color and their faces become pallid. Males rub their bellies in the females' while they swim up and down in the water column. Although our informants did not observe such spawning behavior, our senior interviewee contributed with intriguing new data on divergent male and female behavior in spawning aggregations (Gerhardinger et al., 2006). The information provided by this particular informant was uniquely acquired by him, who clearly knows far more than anyone else in the studied region about goliath grouper aggregations. Thus, some of his local knowledge may not be corroborated by interviewing other fishermen in the region. We understand that in cases where a single individual's local knowledge can potentially contribute to new biological information, efforts should be made to validate this local knowledge by alternative means (Hamilton, 2005), instead of simply discarding it due to the impossibility of cross checking data.

Epinephelus itajara is presumed to be a protogynous species (Smith, 1971), implying that individual fishes would first mature as females, experiencing sex reversal later in life. In protogenic species, the population sex ratio is female dominated, and depends on complex social interactions still not well understood (Shapiro, 1989). However, the reproductive strategy of E. itajara has not yet been completely elucidated regarding protogynous hermaphroditism (Bullock et al., 1992). If the protogeny hypothesis is confirmed for E. itajara, the conservation tactic elaborated and practiced by our informant and his colleagues (targeting males to conserve highly fecund females) may be considered unsustainable. Sex reversal processes are not fast, and the loss of large individuals (primarily males) could potentially result in sperm limitation in spawning aggregations (Beets \& Friedlander, 1999). Changing sex earlier in life (e.g. at a smaller size) would be a possible population response for hermaphroditic fishes experiencing sex related fishing pressure (Platten et al., 2002). However, again such internal population processes are not fast, and will not likely prevent drastic population declines promoted by intense fishing. Sadovy \& Eklund (1999) pointed that one of the major causes of drastic E. itajara population decline in several locations might be the fishing on spawning aggregations. Studying the underlying dynamics of E. itajara spawning aggregations will be an important task for future conventional ichthyologic approaches. However, there is strong evidence showing that protecting such aggregations is extremely important on a conservation perspective.

Epinephelus itajara usually preys on slow organisms, but this fish can accelerate explosively when pursuing preys (Sadovy \& Eklund, 1999). The jaws format of E. itajara suggests it is an ambush hunter, capturing its preys by water suction (Weaver, 1996). The small canine teeth typical of $E$. itajara may reveal a preference for crustaceans, especially lobsters and crabs (Randall, 1967; Bullock \& Smith, 1991; Sadovy \& Eklund, 1999). However, fish, octopuses and even marine turtles were already found as preys of the largest individuals (Randall, 1983; Bullock \& Smith, 1991). A strong similarity is noticed between the feeding habits of E. itajara in our study based on fishermen's LEK and those determined by conventional ichthyology research in the northern hemisphere (Table 3). Lobsters, crabs, octopuses, catfishes, spadefishes and other fishes, including several tetraodontiforms, amongst others, are all common prey items in both populations of this fish. Furthermore, as spear and long-line fishermen exploit different fishing grounds, we may conclude that lobsters, octopuses and spadefish consist of 
important feeding resources for E. itajara in the outer bay, while catfishes are important prey items for inner bay individuals. Our comparison shows that data on LEK regarding E. itajara natural feeding aspects are reinforced by biological studies conducted elsewhere. Sala \& Sugihara (2005) argues that the understanding of food webs provides important guidelines for marine conservation. Thus, our results adds on a growing body of evidence on how fishermen based information can be reliably used in fisheries management and science (Saenz-Arroyo et al., 2005a; Silvano \& Begossi, 2005).

The loud low-frequency sounds produced by E. itajara are apparently generated by the gas bladder and its associated muscles (Fish \& Mowbray, 1970). These sounds were usually attributed by our informants to an intimidating behavior. However, E. itajara usually does not show agonistic behavior, and is known by most divers as a pacific and curious species. The low sound is produced only in certain occasions, still not well understood. One of the authors (A. A. Bertoncini) had one of his arms sucked by a large sized $E$. itajara $(>100 \mathrm{~cm})$ while closely photographing an individual which was displaying such sounds. This behavior was also observed by Carvalho-Filho (1999) and by one of our spearfishing informants, and can cause injuries by the small canine teeth of the fish if the diver's arms are uncovered with a wetsuit. There has been an increased interest on underwater tourism focused on E. itajara in southern Brazil. Thus, further behavioral studies are needed to understand the factors subjacent to agonistic behavior, in order to provide a safe dive to tourists intending to get close to large E. itajara.

Large sized dying $E$. itajara individuals were frequently seen by our informants, who regarded this as a common event. Local artisanal fishermen in northern Brazil (Bahia) have also observed dying E. itajara individuals within the estuary (LCG pers. observ.). Gilmore et al. (1978) and Smith (1976) have registered E. itajara mortality events in the Gulf of Mexico as a function of low temperatures and red tides, respectively. Marine fish mortality events are common in the coast of Santa Catarina and need a further specialized investigation. The underlying causes of such fish mortalities remain unknown.

Our studied E. itajara population shows a similar habitat distribution to that observed for populations of this fish in the Northern Hemisphere. In both cases, E. itajara are found from shallow bays and estuaries to the open ocean (Odum, 1971). In the Northern Hemisphere, this fish species shows a size-related habitat shift. Juveniles ( $<110 \mathrm{~cm}$ total length) are found in well-developed fringing red mangrove shorelines, especially in sites with high structural complexity, soft sediment and eroded shorelines (Frias-Torres, 2006). Adults are found in coral reefs, isolated patch reefs, reef/rock ledges, and artificial structures (Bohnsack et al., 1999; Sadovy \& Eklund, 1999). Considering that in the present study E. itajara larger than $150 \mathrm{~kg}$ have not been caught by the long-line fishing in the inner bay, two hypotheses emerged: i) larger individuals $(>150 \mathrm{~kg})$ are not abundant or do not inhabit the inner Babitonga bay; ii) larger individuals $(>150 \mathrm{~kg})$ are not vulnerable to long-line fishing.

Our E. itajara studied population is located in the southernmost distribution limit known for this species (HostimSilva et al., 2005). Climatic factors related to high latitudes can generate wider water temperature fluctuations. Thus, we may advance with the hypothesis that seasonal effects might play an important role in determining E. itajara local migration patterns in the studied site. In the Northern Hemisphere, large individuals of E. itajara can apparently settle at the same locality for more than one year at coastal and offshore sites (Smith, 1976). This behavior was also observed in low latitude coastal and oceanic sites in Northern Brazil (LCG, pers. observ.).

We observed a sharp contradition between the oppinion of the two groups of informants (spear-fishing vs long-line) regarding local conservation status of E. itajara. Thus, considering that both categories of fishermen explore the same E. itajara population, the information provided by our informants led us to three possible trends in historical population abundance of this fish: decreased abundance (all spear-fishing informants), stable or even increased abundance (longline informants). We hipothesize that this contradition has its roots in the different ways both groups experience and accumulate knowledge on the resources they exploit (Table 4). The use of different fishing gears might influence the process of LEK generation, thus influencing fishermen perception on fish abundance fluctuations over time. Albeit dealing with the same E. itajara population, it seems that the two fishermen's categories (long-line $v s$ spear-fishing) exploit distinct life stages (juveniles $v s$ adults). Thus, as spear-fishing informants constitute the only source of information on $E$. itajara larger than $150 \mathrm{~kg}$, we may consider the hypothesis of local growth overfishing. In this sense, while small sized $E$. itajara are still apparently abundant (taking into account longline informant perceptions), this species may not be allowing to grow large, as larger adults are becoming scarce.

Table 4. Hypothesized factors influencing the generation of local ecological knowledge on the goliath grouper Epinephelus itajara among long-line and spear fishermen.

\begin{tabular}{lll}
\hline Factor & Spear fishermen & Long-line fishermen \\
\hline $\begin{array}{l}\text { Segment of the } E \text {. itajara } \\
\text { population observed }\end{array}$ & $\begin{array}{l}\text { Mainly large fish up to 300 kg inhabiting the outer } \\
\text { bay }\end{array}$ & Fishes up to 150 kg inhabiting the inner bay \\
$\begin{array}{l}\text { Environmental } \\
\text { contact/cognition }\end{array}$ & $\begin{array}{l}\text { Fishermen, visually observe the underwater marine } \\
\text { environment where the resource is found }\end{array}$ & $\begin{array}{l}\text { Fish can be caught year round } \\
\text { Knowledge is accumulated mainly through the use of } \\
\text { Long-lines, from "outside" of the marine } \\
\text { environment }\end{array}$ \\
$\begin{array}{l}\text { Vulnerability of the } \\
\text { species to gear type }\end{array}$ & $\begin{array}{l}\text { An apparent higher resource vulnerability provides } \\
\text { more oportunities for fishermen to develop a clear } \\
\text { perception on species population status }\end{array}$ & $\begin{array}{l}\text { An apparent lower resource vulnerability provides } \\
\text { less oportunities for fishermen to develop a clear } \\
\text { perception on species population status }\end{array}$ \\
\hline
\end{tabular}


Ferreira \& Maida (1995), after evaluating the oppinion of experienced fishermen and researchers, suggested that abundance of E. itajara had considerably decreased in Brazil along the past decades. Existent catch statistics on E. itajara are apparently not capable to subsidize stock evaluations in Brazil (Ferreira \& Maida, 1995; UNIVALI, 2002). LEK assessments might thus be one of the only affordable ways to recover the history of this species population status in this country. LEK and other anecdotal information are increasingly being acknowledged as an important mechanism of recovering and assessing marine species at risk (Sáenz-Arroyo, 2005a).

\section{Conclusions}

We were able to register a broad and important range of $E$. itajara biological aspects, as well as socioeconomic aspects of fisheries targeting the species. Furthermore, we observed a great similarity between data on biological aspects of $E$. itajara gathered from the scientific biological literature in the Northern Hemisphere (e.g. Bullock et al., 1992; Sadovy \& Eklund, 1999; 1999; Frias-Torres, 2006) and data from fishermen's LEK at our study area.

Although the local spear-fishing culture is not as traditional nor as old as the long-line fishing, we observed a detailed ecological knowledge system inherent to spear-fishermen. A detailed knowledge on the habitat and behavior of the resource exploited is required from fishermen in order to make spear-fishing economically viable. Additionally, the primarily visual and closer contact with the marine ecosystem might accelerate the accumulation of LEK on the exploited resources.

Although our study indicates that there is a low economical dependence of fishermen on E. itajara, we call attention to the importance of further research focused in socioeconomic aspects of E. itajara artisanal fisheries. Such research will be of great importance for the delineation of reasonable conservation measures aimed to protect this species on a national level (e.g. evaluating the social impacts of the ongoing moratorium on fishermen communities economy).

This research is part of a broader effort to approach several issues on E. itajara conservation in Brazil. The results herein presented will hopefully help to build a healthy dialogue between researchers, fishermen and managers. On the other hand, there are few local institutional mechanisms to assure that LEK contributes effectively in the management of the local marine environment. Fostering the links between researchers, governmental environmental organizations, fishermen communities and local non-governmental organizations may improve the mechanisms through which LEK is officially taken into account in the decision-making process.

Currently, there is an ongoing process to implement a Marine Protected Area (MPA) in the studied region, which will encompass the totality of the inner bay and portions of the outer Babitonga bay. The foreseen category of MPA will allow traditional artisanal fishermen to continue exploiting the area. The Brazilian legislation on protected areas also foresees a management discussion forum for this MPA, which will include a broad range of local community representatives. The data set herein presented is therefore a practical evidence that joining scientific and local ecological knowledge will likely benefit $E$. itajara local conservation and management practices by adding important new biological data into the decision-making process.

\section{Acknowledgments}

We thank all informants that kindly shared their knowledge and warmly received us in their homes for long periods of productive conversation. Without the information and references from several fishermen, fish markets and fishermen association staff, it would not be possible to identify our informants, and for that we are very grateful. We thank comments and suggestions on the manuscript from Ricardo Corbetta, Sarah FriasTorres, Fernando G. Becker and two anonymous referees. This work would not be accomplished without the logistic support from Instituto Vidamar (www.vidamar.org.br) and the financial support given by Transpetro Transportes S/A to the "Meros do Brasil" research project.

\section{Literature Cited}

Beets, J. \& A. Friedlander. 1998. Evaluation of a conservation strategy: A spawning aggregation closure for red hind, Epinephelus guttatus, in the U.S. Virgin Islands. Environmental Biology of Fishes, 55: 91-98.

Bohnsack, J. A., D. B. McClellan, D. E. Harper, G. S. Davenport, G. J. Konoval, A. M. Eklund, J.P. Contillo, S. K. Bolden, P. C. Fischel, G. S. Sandorf, J. C. Javech, M. W. White, M. H. Pickett, M. W. Hulsbeck, J. L. Tobias, J. S. Ault, G. A. Meester, S. G. Smith \& J. Luo. 1999. Baseline data for evaluating reef fish populations in the Florida Keys, 1979-1998. NOAA Tech Mem NMFS-SEFSC-427.

Bullock, L. H., M. D. Murphy, M. F. Godcharles \& M. E. Mitchell. 1992. Age, growth, and reproduction of jewfish Epinephelus itajara in the eastern Gulf of Mexico. Fishery Bulletin, 90: 243-249.

Bullock, L. H. \& G. B. Smith. 1991. Seabasses (Pisces:Serranidae), Memoirs of the Hourglass Cruises, 8(2): 1-243.

Carvalho-Filho, A. 1999. Peixes da Costa Brasileira. São Paulo, Ed.Melro, 320p.

Colin, P. L. 1994. Preliminary Investigations of Reproductive Activity of the Jewfish, Epinephelus itajara (Pisces: Serranidae). Proceedings of the Gulf and Caribbean Fisheries Institute, 43: 138-147.

Davis, A. \& J. R. Wagner. 2003. Who knows? On the importance of identifying "experts" when researching local ecological knowledge. Human Ecology, 31: 463-489.

Eklund, A. M. \& J. Schull. 2001. A stepwise approach to investigate the movement patterns and habitat utilization of goliath grouper, Epinephelus itajara, using conventional tagging, acoustic telemetry and satellite tracking. Pp 189-216. In: Nielsen, J. L. (Ed.). Electronic tagging and tracking in marine fisheries. Amsterdam, Kluwer Academic Publishers, 484p.

Ferreira, B. P. \& M. Maida. 1995. Projeto Mero: apresentação de resultados preliminares. Boletim Técnico-Científico do CEPENE, 3(1): 210-210.

Ferreira, B.P., M. Hostim-Silva, L.C. Gerhardinger \& A. A. Bertoncini. 2006. Research and conservation of groupers in Brazil. Boletín Especies Amenazadas, IUCN, v. 11. 
Fish, M. P. \& W. H. Mowbray. 1970. Sounds of western north Atlantic fishes: a reference file of biological underwater sounds. Baltimore, The John Hopkins Press, 205p.

Frias-Torres, S. 2006. Habitat use of juvenile goliath grouper Epinephelus itajara in the Florida Keys, USA. Endangered Species Research, 1: 1-6.

Gerhardinger, L. C., M. Hostim-Silva, R. P. Medeiros, R.C. Marenzi. (in press). Conhecimento Ecológico Local de Pescadores da Baía Babitonga, Santa Catarina, Brasil: Peixes da Família Serranidae. Acta Scientiarium. Biological Sciences.

Gerhardinger, L.C., A. A. Bertoncini \& M. Hostim-Silva. 2006. Local ecological knowledge and Goliath grouper spawning aggregations in the South Atlantic Ocean: Goliath grouper spawning aggregations in Brazil. SPC Traditional Marine Resource Management and Knowledge Information Bulletin, 20: 33-34.

Gilmore, R. G., L. H. Bullock \& F. H. Berry. 1978. Hypothermal mortality in marine fishes of south-central Florida January 1977. Northeast Gulf Science, 2(2): 77-97.

Hamilton, R. J. 2005. Indigenous ecological knowledge (IEK) of the aggregating and nocturnal spawning behaviour of the longfin emperor, Lethrinus erythropterus. SPC Traditional Marine Resource Management and Knowledge Information Bulletin, 18: 9-17.

Heemstra P.C. \& J.E., Randall. 1993. FAO species catalogue: Groupers of the world (Family serranidea, subfamily Epinephelinae). An annotated and illustrated catalogue of the grouper, rockcod, hind, coral grouper and lyretail species known to date. FAO Fisheries Synopis, 16(125):1-382.

Hostim-Silva, M., A. A. Bertoncini, L. C. Gerhardinger \& L. F. Machado. 2005. The Lord of the Rocks conservation program in Brazil: the need for a new perception of marine fishes. Coral Reefs, 24: 74.

Huntington, H. P. 2000. Using Traditional Ecological Knowledge in Science: Methods and Applications. Ecological Applications, 10(5): 1270-1274.

Huntsman, G.R., J. Potts, R. W. Mays \& D. Vaughan. 1999. Groupers (Serranidae, Epinephelinae): endangered apex predators of reef communities. In: Musick JA (Ed.) Life in the slow lane: ecology and conservation of long-lived marine animals. American Fisheries Society Symposium , 23: 217-231.

IBAMA. 1998. Proteção e controle de ecossistemas costeiros: manguezal da Baía de Babitonga. IBAMA, Brasília, 145p.

Chan Tak-Chuen, T. \& Padovani Ferrera, B. 2006. Epinephelus itajara. In: IUCN 2006. 2006 IUCN Red List of Threatened Species. Available at www.iucnredlist.org. Accessed in December/2006.

Johannes, R. E. 1998. The case for data-less marine resource management: examples from tropical nearshore finfisheries. Trends in Ecology and Evolution, 13: 243-246.

Johannes, R. E., M. M. R. Freeman \& R. J. Hamilton. 2000. Ignore fishers' knowledge and miss the boat. Fish and Fisheries, 1(3): 257-271.

Lichtenstein, M. G. G. 1822. Die Werke von Marcgrave und Piso uber die Naturgeschichte Brasiliensis, erlautert aus den wieder aufgefundenen Originalzeichnungen. Abbildungen. IV. Fische. Abhandlungen Akademie Wissenschaften. Berlin (1820-1821): 267-288.

Morris, A. V., C. M. Roberts \& J. P. Hawkins. 2000. The threatened status of groupers (Epinephelinae). Biodiversisty and Conservation, 9: 919-942.

Odum, W. E. 1971. Pathways of energy flow in a southern Florida estuary. Univ. Miami Sea Grant Progr. Sea Grant Technical Bulletin, N.7, 162p.
Pinheiro, L. \& M. Cremer. 2004. Sistema pesqueiro da Baía de Babitonga, litoral norte de Santa Catarina: uma abordagem etnoecológica. Desenvolvimento e Meio Ambiente, 8: 59-68.

Platten, J. R., Tibbetts, I. R. \& Sheaves, M. J. 2002. The influence of increased line-fishing mortality on the sex ratio and age of sex reversal of the venus tusk fish. Journal of Fish Biology, 60: 301-318.

Randall, J. E. 1967. Food habits of reef fishes of the West Indies. Studies in Tropical Oceanography, Institute of Marine Science, University of Miami, 5: 665-847.

Randall, J. E. 1983. Caribbean reef fishes. Second edition. Neptune City, T.F.H. Publications, 350p.

Roberts, C. M. \& J. P. Hawkins. 2000. Fully-Protected Marine Reserves: a guide: Washington, DC, USA and Environmental Department, University of York, York, UK, 131p.

Sáenz-Arroyo, A., C. M. Roberts, J. Torre \& M. Carino-Olvera. 2005a. Using fishers' anecdotes, naturalists' observations and grey literature to reassess marine species at risk: the case of the Gulf grouper in the Gulf of California, Mexico. Fish and Fisheries 6: 121-133.

Sáenz-Arroyo, A., C. M. Roberts, J. Torre, M. Carino-Olvera \& R. R. Enrýq. 2005b. Rapid environmental shifting baseline among fishers from the Gulf of California . Proceedings of the Royal Society, 272: 1957-1962.

Sadovy, Y. \& W. L. Cheung. 2003. Near extinction of a highly fecund fish: the one that nearly got away. Fish and Fisheries, 4: 86-99.

Sadovy, Y. \& A. Eklund. 1999. Synopsis of Biological Data on the Nassau Grouper, Ephinephelus striatus, and the Jewfish, E. itajara. NOAA Technical Report, 65p.

Sala, E. \& G. Sugihara . 2005. Food web theory provides guidelines for marine conservation. Pp. 170-183. In: Belgrano, A., U. Scharler, J. Dunne \& B. Ulanowicz (Eds.). Aquatic Food Webs: An Ecosystem Approach. Oxford, Oxford University Press.

Seixas, S. S. \& A. Begossi. 2001. Ethnozoology of Fishing Communities from Ilha Grande (Atlantic Forest Coast, Brazil). Journal of Ethnobiology, 21(1): 107-135.

Shapiro, D. 1989. Sex change as an alternative life-history style. Pp. 177-195. In: Burton, M. N. (Ed.). Alternative life history styles of animals. Dordrecht, Kluwer Academic Publishers.

Silvano, R. A. M. \& A. Begossi. 2005. Local knowledge on a cosmopolitan fish ethnoecology of Pomatomus saltatrix (Pomatomidae) in Brazil and Australia.. Fisheries Research, 71:43-59.

Smith, C. L. 1971. A revision of the American groupers: Epinephelus and allied genera. Bulletin of the American Museum of Natural History, 146:67-242.

Smith, G. B. 1976. Ecology and distribution of eastern Gulf of Mexico reef fishes. Florida Marine Research Publications, N.19, 78p.

Tiago, A. S. 1941. São Francisco: notícia estatístico-descritiva. Instituto Brasileiro de Geografia e Estatística, Departamento Estadual de Estatística. Imprensa oficial do Estado, Publicação n.19. 2ed.

UNIVALI. 2002. Boletim estatístico da pesca industrial de Santa Catarina - Ano 2001: ações prioritárias ao desenvolvimento da pesca e aqüicultura no sul do Brasil. Itajaí, UNIVALI, PróReitoria de Ensino, Centro de Educação Superior de Ciências Tecnológicas, da Terra e do Mar. 89p.

Weaver, D. C. 1996. Feeding ecology and ecomorphology of three sea basses (Pisces: Serranidae) in the northeastern Gulf of Mexico. Unpublished Msc Dissertation. University of Florida, Gainesville, 94p.

Submitted July 2006 Accepted December 2006 